\title{
Effect of crop residue management on soil organic carbon, soil organic matter and crop yield: An overview
}

\author{
Renu Kumari* \\ Division of Soil and Crop Management, ICAR-Central Soil Salinity Research Institute \\ (CSSRI), Karnal-132001 (Haryana), India \\ Ranbir Singh \\ Division of Soil and Crop Management, ICAR-Central Soil Salinity Research Institute \\ (CSSRI), Karnal-132001 (Haryana), India \\ Neeraj Kumar \\ Division of Irrigation and Drainage engineering, ICAR-Central Soil Salinity Research \\ Institute (CSSRI), Karnal-132001 (Haryana), India \\ ${ }^{*}$ Corresponding author. E-mail: renuchoudhary.choudhary48@gmail.com

\begin{abstract}
Soil is a very important factor of the plant growth and crop yield. But now a days, very small area of the soil can actually be fertile for agriculture, and if we manage improperly it can be depleted. So the big problem, how we manage and increase the fertility of soil. It has been reported that soil organic carbon and soil matter is the most important indicator of soil quality and soil health. It is also beneficial for agricultural sustainability. In this review, we summarized how crop residue management affects soil organic carbon (SOC), soil organic matter (SOM), soil aggregation, effect of residue burning and crop productivity in different cropping system. Proper use of crop residue can increase or maintain the physical and chemical properties of SOM and improve the quality of soil. Manure or crop residue alone may not be adequate to maintain SOC levels. Knowledge and assessment of changes (positive or negative) in SOC and SOM with time is still needed to evaluate the impact of different management practices.
\end{abstract}

Keywords: Soil organic carbon, Crop yield, Crop residue, Soil properties

\section{INTRODUCTION}

Previous work held by many scientist demonstrated that the soil nutrients concentrations such as nitrogen, organic carbon, and phosphorus are good indicators of soil health and productivity of various crops because of their favorable effects on the soil properties like biological, chemical, and physical (Karami et al., 2012). Soil is a non renewable natural resource on the human time scale (Jenny, 1980) or it is a living, dynamic, natural thing which plays vital roles in terrestrial ecosystems. Indirectly soil is the key of life and health for the beneficiary of humans and other kind of animal. It is a source of agriculture food production. Soil quality maintenance is mandatory for sustained productivity of food, the decomposition of wastes, storage residue returned nutrient in to the soil of heat, carbon sequestration, and the gases exchange. Now a days, a very small area of the soil can actually be used for growing food crops, and if we will not maintain, it may be depleted, destroyed or polluted (Brady and Weil, 2000). The estimated percentage of the soil that covers $11 \%$ area of plantation and $38 \%$ area of agriculture in

\section{Article Info}

https://doi.org/

10.31018jans.v11i3.2152

Received: July 27, 2019

Revised: September 1, 2019

Accepted: September 7, 2019

\section{How to Cite}

Kumari, R. et al. (2019). Effect of crop residue management on soil organic carbon, soil organic matter and crop yield: An overview. Journal of Applied and Natural Science, 11 (3): 712- 717 https:// doi.org/10.31018jans.v11i3 .2152 
management of soil and soil carbon, soil nutrients and whole health of soil which can serve as an early warning system to investigate impairments that threaten future productivity (Clapp et al., 2000).

Since last two decades, people are taking interest to improve the quality of soil throughout the world. They recognize the fragility of natural resources, or the need of their protection to sustain development. Now a days, scientists develop many technologies to sustain soil health, soil quality and for increasing food production. Among of them, residue management is the technology which is beneficial for soil and crop yield.

Many scientists reported that straw of crop is full of organic carbon and nutrient, so it is important organic fertilizer which can replace the chemical fertilizers (Duiker and Lal, 1999; Saroa and Lal, 2003; Tan et al., 2007; Bakht et al., 2009).

Lal et al. (1995); Farquharson et al. (2003) and Farquharson et al. (2004) reported that agricultural management system greatly affects the organic matter like soil carbon, soil quality and soil health. Soil organic carbon is terrestrial pool for carbon, nitrogen, phosphorus and their cycling. If the organic matter of soil increases it, affects the properties of soil, conserving water and available soil nutrients. These increments ultimately lead to increase the quantity of crop yield (Berzsenyi et al., 2000 and Onemli, 2004). Loveland and Webb (2003). If the organic carbon of soil and its organic matter decrease too much, it widely affects the productive capacity of soil which will be then compromised by deterioration in soil properties and by impairment of nutrient cycling mechanisms

Christian and Miller (1986) reported in Western Europe that crop residues deposition at the soil surface cause poor mineralization can impede crop establishment and it provide a favorable environment for slugs. Cannell and Hawes (1994) observed that by plowing or chiseling the residues, their incorporation into the soil is preferred instead of residue burning, because of legal restrictions on emission of carbon di oxide. According to environmental rule, use of herbicides should be limited and mechanical methods should be used for weeds control. In regions of Africa, crop residues are used for feeding cattle while soil mulching could help water conservation. Mandal et al.( 2004) and Zhang et al. (2014) observed that the effects of crop straw incorporation on the physical properties of soil (e.g. the soil structure, soil water content, etc. In this review, we summarized how resource conservation technologies (crop residue management) affect soil organic carbon (SOC), soil organic matter (SOM), soil aggregation effect of residue burning and crop productivity in different cropping systems.

Crop residue: Crop residue management (CRM) is a widely used in agriculture land conservation practices. It provides various amounts of soil nutrients for increasing the production of crop. In addition to affecting whole properties of soil like physical, chemical and biological, crop residues also affect the movement of water, infiltration rate , and runoff water. Residue influences the temperature of soil by insulating the soil surface from the sun's radiant energy. If the amount of crop residue increases on soil surface, it reduces evaporation rates. Residue increase a greater organic matter content by covered soils surface than bared soils. Observations have shown that soils retain more moisture when it is retained on the soil surface as compared to residue incorporation (Singh and Sidhu, 2014).

Effect of residue on crop yield: Paikaray et al. (2001) reported $80 \mathrm{~kg} \mathrm{~N} / \mathrm{ha}$ yield with wheat residue incorporation. Yield was statistical at par with cowpea in crop rotation and significantly lowered as compared to with residue incorporation statistically similar without organic nitrogen and $120 \mathrm{~kg}$ nitrogen per hectare. Thakur et al. (1995) observed $40 \mathrm{~kg}$ nitrogen saving per hectare with residue incorporation in field.

Inorganic fertilizer, wheat straw and mixture of rice can however, increase the yield of rice and wheat in rice-wheat cropping systems. Of course, proper crop residue incorporation and fertilizer management practices can reduce nitrogen immobilization into the soil. Sharma (2002) observed that the use of $40 \mathrm{~kg}$ nitrogen per hectare at the time of residue incorporation in wheat crop, and similar percentage of nitrogen used during transplanting and rest at panicle initiation increased straw yield $0.51 .0 \mathrm{t} / \mathrm{ha}$, grain yield by $0.5-0.7 \mathrm{t} / \mathrm{ha}$ apparent nitrogen recovery by $10 \%$.showing residue incorporation was the better result and reported good available $\mathrm{N}$ content in soil than $\mathrm{N}$ use along with transplanting (TPR). Zhang et al. ( 2016) reported that the incorporation of straw (especially in rate of 13500 kilogram per hectare) was a good method for increasing soil fertility and better yield production in semiarid region of China.

Guo-Wei et al. (2009) reported that $2.65 \%$ average of grain yield was increased with incorporation of crop residue as compared to without crop residue. However, the incorporation effect of straw on the biomass of yield was better in rice crop. Grain and straw yields of rice were affected significantly. Alone application of wheat straw 5 or 10 t/ha gave better rice grain yield as compared to control sets. Application of wheat residue incorporation over its removal or burning are proved better result. Higher use of chemical fertilizer alone, from 50 to 75 and $100 \%$ of the recommended dose of $\mathrm{N}$, also improved crop yield significantly. Result revealed that the application of both things wheat straw and doses of nitrogen increased the grain and straw yields of rice 
(Kumar et al., 2003). Gao et al. (2018) reported that the dry weight of corn plant root and summer yield was higher $18.5 \%$ and $15.1 \%$ in the residue treatment field. They recommended that appropriate amount of crop residue returned the nutrients in the field which is beneficiary for corn growth.

Effect of residue on SOC, SOM and soil nutrients: The incorporation of crop residue either partially or completely in the field depends upon cultivation method. Crop straw incorporation improves soil organic carbon and soil nutrients contents. It is beneficial for recycling nutrients residue, ploughing is important in immobilization of nutrients (especially nitrogen), and the better ratio of $\mathrm{C}: \mathrm{N}$ needs to be corrected by applying extra nitrogen fertilizer at the time of residue incorporation (Yadvinder Singh et al., 2005). In some studies, it is also reported that the yield of rice was reduced in first 3 years of straw incorporation 30 days prior to rice planting due to crop residue applied in field caused immobilization of soil nitrogen. But in later years, it did not affect the yield.

The results obtained by Zhang et al. (2016) indicated that straw incorporation significantly increased the organic carbon concentration and storage levels as compared to without incorporation of straw, where the increase was probably associated with the amount of crop residues incorporated into the soil, as suggested previously (Malhi et al., 2011). Chaudhary et al.(2014) reported that retention and incorporation of residue caused a significant increment in total water stable aggregates $(15.65 \%)$ in $0-15 \mathrm{~cm}$ in surface soil and $7.53 \%$ in sub-surface soil $(15-30 \mathrm{~cm})$, which depicted that the use of crop residue, can increase 2.1-fold higher water stable aggregates as compared to the other treatments without residue incorporation/retention.

The study of Mambanengwe and Maofuna (2005) conducted on soil fertility gradient across 120 farms located on granitic derived sandy soil in three agro ecological regions of Zimbabwe indicated that soil organic carbon was consistently increased in most productive than least productive fields with in farm, increased soil organic carbon contents under mulch ripping compared with clean ripping were mostly a result of residue retention under the mulch ripping treatments. Gosai et al. (2009) revealed the concentration of soil organic matter was higher under zero-tillage and shallow-tilled plots from under conventional tillage plots. The SOC levels under the high rate $(13500 \mathrm{~kg} / \mathrm{ha})(\mathrm{H})$ incorporation of maize straw and incorporation at medium rate $(9000 \mathrm{~kg} / \mathrm{ha})$ (M) of maize straw treatments differed significantly from those under incorporation of maize straw at a low rate of $4500 \mathrm{~kg} / \mathrm{ha}(\mathrm{L})$ throughout the three years and the soil organic matter level increased as more straw was incorporated and decomposed (Tan et al., 2007). Incorporation of crop residues may be a sustainable and costeffective management practice to maintain the soil ecosystem, the organic carbon of soil levels and to increase soil fertility in European agricultural soils Powlson et al. (2008).

Conservation management practice produced more benefit under those areas where concentration of SOC was found lower such as in Mediterranean soils as reported by Aguilera et al. (2013) and those areas where stockless croplands predominated (Kismanyoky and Toth, 2010; Spiegel et al., 2010). Cvetkov et al. (2010) reported that the application of farmyard manure increases more SOC as compared to residue incorporation in soil under different management systems. Chalise et al. (2019) showed the impact of cover crop and crop residue removal on bulk density, SOC infiltration, retention rate of water and productivity. They showed that returning the crop residue increased SOC and decreased bulk density of soil. They concluded when crop residue applied in the field it add soil carbon, soil nutrient by which fertility and crop productivity would be increases.

Blevins and Frye (1993) observed that crop residues protect the soil from wind and water erosion and high sun's radiation under zero tillage, propitiating soil bio-diversity and enzymatic activity, while improving nutrient efficiency, water economy and soil structure. Under zero tillage crop residues reduced evaporation and maintained moisture fluctuations. However, at the time of harvest different types of tillage system did not show any major influence on the content of moisture while it was higher and reduced at the time of initial tillage and subsequent tillage operations (Srivastava et al., 2000).

The crop residue amount increasing on the soil surface, reduces the evaporation rate (Gill and Jalota, 1996 and Prihar et al., 1996). Consequently, the application of crop residue is the best practice to add organic amendment in soil and cover it surface. For obtaining sustainable development, crop residue properly manages to simultaneously increase soil organic carbon, soil nutrients, water availability and productivity requirement as well as livestock fodder. The availability of plant water content was significantly lower in conventional tillage as compared to zero tillage under ricewheat cropping system as reported by Bhattacharyya et al. (2006) and Bhattacharyya et al.(2008). Box et al. (1996) has shown that maulching of crop residue or partial incorporation of residue in soil by conservation tillage increases the infiltration by reducing surface sealing and decreasing runoff velocity.

Rahman et al. (2005) and Sidhu et al. (2007) reported that mulching of rice crop residue has the potential to control weed growth which is the negative effect of increased weed growth under differ- 
ent tillage treatment as zero or reduced. Mulch control weed biomass due to allelopathic effects and shading might reduce the demand of herbicide and weed competition for nutrients and water. If disease and insects are adequately controlled by economic use of pesticides, mulching would become an attractive residue management option for mitigation of pest pressure in the ricewheat system.

Effect of burning residue: Yadvinder Singh et al. (2010) observed more than $80 \%$ of total rice straw brunt by the famers annually in Punjab in 34 weeks during October-November. This leads to air pollution (particulates, green house gases), respiratory problem occurs, increase in the fog incidences even in distant cities and losses of soil nutrient. The burning of crop residue also effect human and animal health both medically, and by traumatic road accidents due to restricted visibility in North West (NW) India. The peak in number of asthmatic patients in hospitals in NW India coincided with the annual burning of rice residues in surrounding fields.

Vasilica et al. (2014) has reported that the major cause of increasing atmospheric emissions of green house is burning of crop residues in the environment. This burning of crop residue decreases soil organic matter and consequently, with the degradation of the physical, chemical and biological properties of soil and its fertility reduction. Therefore, carbon sequestration in soil is a key solution to limit burning crop residues in the open field. Besides, using crop residue in agriculture field, such as fuel production, is able to deliver new amounts of energy, but also to support farmers for land release and protect the environment.

Thus, the present study revealed the use of crop residue produced is beneficial for soil health, soil organic carbon, soil organic matter and crop yield.

\section{Conclusion}

This review evaluates the knowledge of crop residue management for soil organic carbon, and crop yield. The crop residue offers sustainable and ecologically sound alternatives for meeting the nutrient requirements of soil, crop productivity and environmental quality. Crop residue management is a widely used in cropland conservation practice. This residue increases the SOC and nitrogen mineralization. The residue has complex effects on physical, chemical and biological properties of soil. Changed physical and chemical soil properties by crop residue affect the parameters directly related with soil humidity, temperature and ventilation as well as the degrees of interaction between soil minerals and organic matter. Thus, the crop residue management practices should be selected to enhance crop yields with sustainable soil environment.

\section{REFERENCES}

1. Aguilera, E., Lassaletta, L., Gattinger, A. and Gimeno, B. S. (2013). Managing soil carbon for climate change mitigation and adaptation in Mediterranean cropping systems: a meta-analysis. Agriculture, Ecosystems and Environment, 168: 25-36.

2. Bakht, J., Shafi, M., Jan, M. T. and Shah, Z. (2009). Influence of crop residue management, cropping system and $\mathrm{N}$ fertilizer on soil $\mathrm{N}$ and $\mathrm{C}$ dynamics and sustainable wheat (Triticum aestivum L.) production. Soil and Tillage Research, 104(2): 233-240.

3. Bakker, H. (1990). The World Food Crisis: Food Security in Comparative Perspective. Canadian Scholars Press.

4. Berzsenyi, Z., Győrffy, B., and Lap, D. (2000). Effect of crop rotation and fertilization on maize and wheat yields and yield stability in a long-term experiment. European Journal of Agronomy, 13(2): 225244.

5. Bhattacharyya, R., Kundu, S., Pandey, S. C., Singh, K. P., and Gupta, H. S. (2008). Tillage and irrigation effects on crop yields and soil properties under the rice-wheat system in the Indian Himalayas. Agricultural water management, 95(9): 9931002.

6. Bhattacharyya, R., Singh, R. D., Chandra, S., Kundu, S., and Gupta, H. S. (2006). Effect of tillage and irrigation on yield and soil properties under rice (Oryza sativa)-wheat (Triticum aestivum) system on a sandy clay loam soil of Uttaranchal. Indian journal of agricultural science, 76(7): 405-409.

7. Blevins, R. L., and Frye, W. W. (1993). Conservation tillage: an ecological approach to soil management. Advances in agronomy (USA), 56:111-128

8. Box Jr, J. E., Bruce, R. R. and Agassi, M. (1996). The effect of surface cover on infiltration and soil erosion. Soil erosion, conservation and rehabilitation, 67: 107-123.

9. Brady, N. C. and Weil, R. R. (2000). Elements of the nature and properties of soils (No. 631.4 B733E.). Upper Saddle River, NJ, USA:Prentice hall.

10.Cannell, R. Q. and Hawes, J. D. (1994). Trends in tillage practices in relation to sustainable crop production with special reference to temperate climates. Soil and Tillage Research, 30(2): 245-282.

11. Choudhury, S. G., Srivastava, S., Singh, R., Chaudhari, S. K., Sharma, D. K., Singh, S. K. and Sarkar, D. (2014). Tillage and residue management effects on soil aggregation, organic carbon dynamics and yield attribute in rice-wheat cropping system under reclaimed sodic soil. Soil and Tillage $R e-$ search, 136: 76-83.

12.Christian, D. G. and Miller, D. P. (1986). Straw incorporation by different tillage systems and the effect on growth and yield of winter oats. Soil and Tillage Research, 8: 239-252.

13.Chalise, K.S., S. Singh, B. Wegner, S. Kumar, J.D. Pérez-Gutiérrez, S. Osborne, T. Nleya, J. Guzman, and J.S. Rohila. 2019. Cover crops and returning residue impact on soil organic carbon, bulk density, penetration resistance, water retention, infiltration, and soybean yield. Agron. J. 111:99-108. doi:10.2134/agronj2018.03.0213

14.Clapp, C. E., Allmaras, R. R., Layese, M. F., Linden, D. R. and Dowdy, R. H. (2000). Soil organic carbon and $13 \mathrm{C}$ abundance as related to tillage, crop residue, and nitrogen fertilization under continuous corn 
management in Minnesota. Soil and Tillage Research, 55(3): 127-142.

15.Cvetkov, M., Santavec, I., Kocjan Acko, D. and Tajnsek, A. 2010. Soil organic matter content according to different management system within long-term experiment. Acta agriculturae Slovenica, 95:79-88.

16.Duiker, S. W. and Lal, R. (1999). Crop residue and tillage effects on carbon sequestration in a Luvisol in central Ohio. Soil and Tillage Research, 52(1): 73-81.

17.Farquharson, R. J., Schwenke, G. D. and Mullen, J. D. (2003). Should we manage soil organic carbon in Vertosols in the northern grains region of Australia. Animal Production Science, 43(3): 261-270.

18.Feichtinger, F., Erhart, E. and Hartl, W. (2004). Net $\mathrm{N}$-mineralisation related to soil organic matter pools. Plant Soil and Environment, 50(6): 273-276.

19.Gao, F., B. Zhao, S. Dong, P. Liu, and J. Zhang. 2018. Response of maize root growth to residue management strategies. Agron. J. 110:95-103. doi:10.2134/agronj2017.06.0307

20.Gardiner, D.T., Miller, R.W. (2004): Soils in Our Environment. 10th ed. Prentice-Hall, Inc., Upper Saddle River, New Jersey

21.Gill, B. S. and Jalota, S. K. (1996). Evaporation from soil in relation to residue rate, mixing depth, soil texture and evaporativity. Soil Technology, 8(4): 293301

22.Gosai, K., Arunachalam, A. and Dutta, B. K. (2009). Influence of conservation tillage on soil physicochemical properties in a tropical rainfed agricultural system of northeast India. Soil and Tillage, 105(1) : 63-71.

23.Guo-Wei, XU., Gui-Lu, Tan., Zhi-Qin, Wang., Li-Jun, Liu. and Jian-Chang, Y. (2009). Effects of wheat residue application and site-specific nitrogen management on growth and development in directseeding rice. Acta Agronomica Sinica, 35(4), 685694

24.Jenny, H. (1980). The Soil Resource: Origin and Behavior. Ecol. Stud. 37. Springer-Verlag, New York.

25. Karami, A., Homaee, M., Afzalinia, S., Ruhipour, H. and Basirat, S. (2012). Organic resource management: Impacts on soil aggregate stability and other soil physico-chemical properties. Agriculture, Ecosystems and Environment, 148: 22-28.

26.Kismanyoky, T. and Toth, Z. (2010). Effect of mineral and organic fertilization on soil fertility as well as on the biomass production and $\mathrm{N}$ utilization of winter wheat (Triticum aestivum L.) in a long- term cereal crop rotation experiment (IOSDV). Archives of Agronomy and Soil Science, 56 : 473-479.

27.Kumar, M., Singh, R. R. and Rana, N. S. (2003). Effect of organic and inorganic sources of nutrition on productivity of rice (Oryza sativa) ${ }^{*}$. Indian Journal of Agronomy, 48(3): 175-177.

28.Lal, R., Kimble, J., Levine, E. and Whitman, C. (1995). World soils and greenhouse effect: An overview. Soils and global change, 90: 1-7.

29.Loveland, P. and Webb, J. (2003). Is there a critical level of organic matter in the agricultural soils of temperate regions: a review. Soil and Tillage $R e-$ search, 70(1): 1-18.

30.Malhi, S. S., Nyborg, M., Goddard, T. and Puurveen, D. (2011). Long-term tillage, straw management and $\mathrm{N}$ fertilization effects on quantity and quality of organic $\mathrm{C}$ and $\mathrm{N}$ in a Black Chernozem soil. Nutrient $\mathrm{Cy}$ cling in Agroecosystems, 90(2): 227-241.

31.Mandal, K. G., Misra, A. K., Hati, K. M., Bandyo- padhyay, K. K., Ghosh, P. K. and Mohanty, M. (2004). Rice residue-management options and effects on soil properties and crop productivity. Journal of Food Agriculture and Environment, 2: 224-231.

32. Mambanengwe, F. and Mapfumo, P. (2005). Organic matter management as an underlying cause for soil fertility gradients on smallholder farms in Zimbabwe. Nutrient Cycling in Agroecosystems, 73: $227-$ 243.

33.Onemli, F. (2004). The effects of soil organic matter on seedling emergence in sunflower (Helianthus annuus L.). Plant Soil Environ., 50(11): 494-499.

34.Paikaray, R. L., Mahapatra, B. S. and Sharma, G. L. (2001). Integrated nitrogen management in rice (Oryza sativa)-wheat (Triticum aestivum) cropping system. Indian Journal of Agronomy, 46(4): 592-600.

35.Powlson, D.S., Riche, A.B., Coleman, K., Glendining, M.J. and Whitmore, A.P. (2008). Carbon sequestration in European soils through straw incorporation: limitations and alternatives. Waste Management, 28: 741-746

36.Prihar, S. S., Jalota, S. K. and Teiner. (1996). Residue management for reducing evaporation in relation to soil type and evaporativity. Soil Use Mgt., 12: 150157.

37.Rahman, M. A., Chikushi, J., Saifizzaman, M. and Lauren, J. G. (2005). Rice straw mulching and nitrogen response of no-till wheat following rice in Bangladesh. Field Crops Research, 91(1): 71-81.

38.Ryan, J., Pauw, E. D., Gomez, H., Mrabet, R., Peterson, G. A., Unger, P. W. and Payne, W. A. (2006). Drylands of the Mediterranean zone: biophysical resources and cropping systems. Dryland agriculture, (Ed. 2): 577-624.

39.Saroa, G. S. and Lal, R. (2003). Soil restorative effects of mulching on aggregation and carbon sequestration in a Miamian soil in central Ohio. Land Degradation and Development, 14(5): 481-493.

40.Satiro, L.S., M. R. Cherubon, I.P. Lisboa, R. de Souza Noia, Junior, C. C. Cerri, and C.E. P. Cerri. 2019. Predication of sugarcane yield by soil attribute under straw removal management. Agron. J. 111:14-23. doi:10.2134/agronj2018.01.0021

41.Sharma, S. N. (2002). Nitrogen management in relation to wheat (Triticum aestivum) residue management in rice (Oryza sativa). Indian journal of agricultural science, 72(8): 449-452.

42.Sidhu, H. S., Humphreys, E., Dhillon, S. S., Blackwell, J. and Bector, V. (2007). The Happy Seeder enables direct drilling of wheat into rice stubble. Animal Production Science, 47(7): 844-854.

43.Singh, Y. and Sidhu, H. S. (2014). Management of cereal crop residues for sustainable rice-wheat production system in the Indo-Gangetic Plains of India. Proceedings of Indian National Science Academy, 80(1): 95-114.

44.Spiegel, H., Dersch, G., Baumgarten, A. and Hosch, J. (2010). The International organic nitrogen longterm fertilisation experiment (IOSDV) at Vienna after 21 years. Archives of Agronomy and Soil Science, 56: 405-420.

45.Srivastava, A. P., Panwar, J. S. and Garg, R. N. (2000). Influence of tillage on soil properties and wheat productivity in rice (Oryza sativa)-wheat (Triticum aestivum) cropping system. Indian Journal of Agricultural Sciences, 70(4): 207-210.

46.Tan De-shui., Ji-yun, J. I. N., Shao-wen, H. U. A. N. 
G., Shu-tian, L. I. and Ping, H. E. (2007). Effect of long-term application of $\mathrm{K}$ fertilizer and wheat straw to soil on crop yield and soil $\mathrm{K}$ under different planting systems. Agricultural Sciences in china, 6(2): 200-207.

47.Thakur, R. C., Bindra, A. D., Sood, R. D. and Bhargava, M. (1995). Effect of fertilizer application and green-manuring on physico-chemical properties of soil and grain yield in rice (Oryza sativa)-wheat (Triticum aestivum) crop sequence. Indian Journal of Agronomy, 40(1): 4-13.

48.Vasilica Stan, Gina, Fîntîneru and Mihalache. (2014). Multicriteria Analysis of the effects of field burning crop residues. Bot Horti Agrobo, 42(1):255-262.

49.Yadvinder-Singh, B. S. and Timsina, J. (2005). Crop residue management for nutrient cycling and improving soil productivity in rice-based cropping systems in the tropics. Advances in Agronomy, 85: 269-407.

50. Yadvinder-Singh, Man Gpreet-Singh, Sidhu ,H .S., Khanna, P. K., Kapoor, S., Jain, A. K., Singh, A. K., Sidhu, G. K., Avtar-Singh, Chaudhary, D. P. and Minhas, P. S. (2010). Options for Effective Utilization of Crop Residues, Directorate of Research, Punjab Agricultural University, Ludhiana, India.

51.Zhang, P., Chen, X., Wei, T., Yang, Z., Jia, Z., Yang, B. and Ren, X. (2016). Effects of straw incorporation on the soil nutrient contents, enzyme activities, and crop yield in a semiarid region of China. Soil and Tillage Research, 160: 65-72.

52.Zhang, P., Wei, T., Jia, Z., Han, Q. and Ren, X. (2014). Soil aggregate and crop yield changes with different rates of straw incorporation in semiarid areas of northwest China. Geoderma, 230: 41-49. 